\title{
PRODUCTION OF GLUCOSYLTRANSFERASE BY ERWINIA SP. USING EXPERIMENTAL DESIGN AND RESPONSE SURFACE METHODOLOGY
}

\author{
Haroldo Yukio Kawaguti*; Eiric Manrich; Luciana Francisco Fleuri; Hélia Harumi Sato
}

Laboratório de Bioquímica de Alimentos, Departamento de Ciência de Alimentos, Faculdade de Engenharia de Alimentos, Universidade Estadual de Campinas, Campinas, SP, Brasil

Submitted: November 03, 2003; Returned to authors for corrections: July 25, 2005; Approved: September 20, 2005

\begin{abstract}
Glucosyltransferase produced by strain Erwinia sp. is an intracellular enzyme that catalyzes the formation of isomaltulose from sucrose. Isomaltulose is a non-cariogenic reducing dissacharide commercially used in foods. Response surface methodology and $2^{3}$-factorial central composite design were employed to optimize a fermentation medium for the production of glucosyltransferase by Erwinia sp. in shaken flasks at $200 \mathrm{rpm}$ and $30^{\circ} \mathrm{C}$. The three variables involved in this study were sugar cane molasses (SCM), corn steep liquor (CSL) and yeast extract Prodex Lac SD (YEP). The statistical analysis of the results showed that, in the range studied, all the factors had a significant effect on glucosyltransferase production and the optimum medium composition for enzyme production was (in $\mathrm{g}^{-1}$ ) SCM-100, CSL-60 and YEP-8, which lead to a glucosyltransferase activity of $6.65 \mathrm{U} \mathrm{mL}^{-1}$.
\end{abstract}

Key words: glucosyltransferase, isomaltulose, optimization, response surface

\section{INTRODUCTION}

Isomaltulose [O- $\alpha$-D-glucopiranosyl- $(1 \rightarrow 6)-\beta$-D-frutofuranose] is a reducing disaccharide commercially obtained by the enzymatic conversion from sucrose catalyzed by a microbial glucosyltransferase as shown in Fig. 1. Several microorganisms including Protaminobacter rubrum (2), Erwinia rhapontici (1), Klebsiella planticola (4), can convert sucrose into isomaltulose. The interest on isomaltulose is due to the non-cariogenic property, low hydrolysis speed and formation of monossacharides in the organism. Moreover, another important characteristic of this disaccharide is the possibility of converting this sugar to a sugar-alcohol mixture with low caloric value and non-cariogenic property known as Isomalt ${ }^{\circledR}$ or Palatinit ${ }^{\circledR}$. Isomaltulose is naturally present in small quantities in honey and sugar cane extract $(4,14,17)$. The low cariogenicity and the inhibitory action of insoluble polyglucan synthesis from isomaltulose were demonstrated in experimental studies with rats $(12,13)$ and in human studies (18). Isomaltulose presents about $50 \%$ the sweetness of sucrose $(2,4,14,17)$ and similar physical and organoleptics properties $(1,4,16)$. When used as sucrose substitute in candies and chocolates differences in the sweetness have not been noticed (16). In the organism, isomaltulose is hidrolysed by isomaltase and absorbed as glucose and frutose (17). However, the hydrolysis velocity and the absorption are lower when isomaltulose is used instead of sucrose. Isomaltulose has been recommended as potential parenteral nutrient for diabetics and non-diabetics $(5,6,16)$. In experimental studies with rats, isomaltulose did not show teratogenic and mutagenic effects or any type of toxicity, being safety for the use in foods $(7,16)$. The application of experimental design and response surface methodology in fermentations process can result in improved product yields, reduced process variability and development time and over all costs (12). In this work, the effect of both nitrogen source (corn steep liquor and yeast extract) and carbon source concentrations (sugar cane

*Corresponding Author. Mailing address: Laboratório de Bioquímica de Alimentos, Departamento de Ciência de Alimentos, Faculdade de Engenharia de Alimentos, UNICAMP, Av. Monteiro Lobato 80, C.P.6121. 13083-862, Campinas, SP, Brasil. Tel.: (+5519) 3788-2175. Fax.: (+5519) 37882153. E-mail address: kawaguti@fea.unicamp.br 


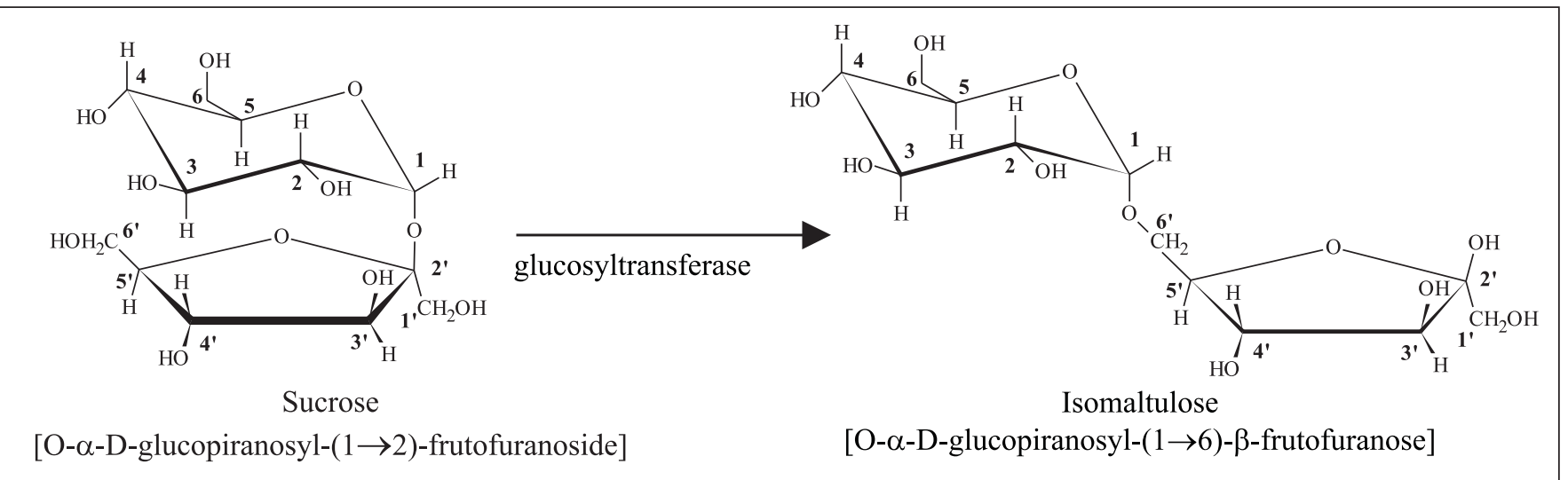

Figure 1. Conversion of sucrose into isomaltulose by glucosyltransferase.

molasses) on glucosyltransferase production by Erwinia sp. was studied at $30^{\circ} \mathrm{C}$ and the optimal conditions for enzyme production were determined.

\section{MATERIALS AND METHODS}

\section{Microorganism and culture maintenance}

The strain Erwinia sp. D12 producer of glucosyltransferase is able to convert sucrose into isomaltulose and it has been isolated in the Laboratory of Food Biochemistry, of the College Food Engineering/UNICAMP. The strain Erwinia sp. D12 was maintained on agar slants composed of $6 \%(\mathrm{w} / \mathrm{v})$ sucrose, $4 \%$ $(\mathrm{w} / \mathrm{v})$ peptone, $0.4 \%(\mathrm{w} / \mathrm{v})$ beef extract and $2 \%(\mathrm{w} / \mathrm{v})$ agar and it was stored at $5^{\circ} \mathrm{C}$.

\section{Culture medium optimization using Experimental Design and Response Surface Methodology}

The in vitro study for culture medium optimization (in shaken flasks) was carried out using experimental design and response surface methodology (RSM). Three $2^{3}$-factorial central composite design $\left(2^{3}-\mathrm{FCCD}\right)$ was used with a combination of the concentration levels of the independent variables. All data were treated with the aid of STATISTICA ${ }^{\circledR} 5.0$ from Statsoft Inc. (2325 East 13 th Street, Tulsa, OK, 74104, USA). The FCCD for $k$ factors, codified as $x_{1}, \ldots, x_{k}$, was composed of three parts: factorial (or cubical), containing a total of $\mathrm{n}_{\text {fact }}$ points of coordinates $x_{i}=-1$ or $x_{i}=+1$, for all $i=1, \ldots, k$; axial (or in star), formed by $n_{\alpha x}=2 \mathrm{k}$ points with all the null coordinates except one, wich is equal to a certain value $\alpha$ (ou $-\alpha$ ), where $\alpha=n_{\text {fact }}{ }^{1 / 4}$; and a total of $n_{\text {centr }}$ assays carried out at the central point, where $x_{1}=\ldots x_{k}=0$. Central points provide additional degrees of freedom for error estimation, which increases power when testing the significance of effects and the $\alpha$ value is the distance of the axial points. The dependent variables $X_{i}$ were codified according to the following equation:

$$
x_{i}=\left(X_{i}-X_{0}\right) / \Delta x_{i}, \mathrm{i}=1,2,3, \ldots, k
$$

where $X_{0}$ corresponds to the value of the central point; $x_{i}$ is the non-dimensional value of the independent variable; $X_{i}$ corresponds to the real value of the independent variable; $X_{0}$ is the real value of the independent variable at the central point; and $\Delta x_{i}$ is the variation of the real value of the variable $i$, corresponding to the variation of a unit for the non-dimensional value of the variable $i$. The complete quadratic model for the $k$ factors is given by the following equation:

$$
y=\beta_{0}+\sum_{i} \beta_{i} x_{i}+\sum_{i} \beta_{i i} x_{i}^{2}+\sum_{i<j} \sum_{j} \beta_{i j} x_{i} x_{j}+\varepsilon
$$

where the values for $\beta$ are estimated from the polynomial coefficients and the $X_{i}$ values represent the codified values. The three $2^{3}$-FCCD included 8 factorial points, with six axial points $(\alpha)$ and three replicates at the central point resulting in a total of 17 assays per experiment. The three FCCD are shown in Tables 1, 2 and 3 and they were used to study the effect of the following components: sugar cane molasses (Companhia Energética Santa Elise), corn steep liquor (Corn Products Brasil) and yeast extract Prodex Lac SD ${ }^{\circledR}$ (Prodesa produtos especiais para alimentos S.A.) in the production of glucosyltransferase by strain Erwinia sp. D12 so that both the maximum enzymatic activity and reduced costs for the fermentation process could be aimed.

\section{Inoculum and fermentation conditions}

The strain was grown in $250 \mathrm{~mL}$ Erlenmeyer flasks containing $50 \mathrm{ml}$ of a seed culture medium according to $2^{3}$-FCCD (Tables 1 , 2 and 3), for $15 \mathrm{~h}$ at $30^{\circ} \mathrm{C}$ in a rotary shaker (New Brunswick Scientific, Edison, N.J., U.S.A). An aliquot of $5 \mathrm{~mL}$ of the seed culture was transferred to $250 \mathrm{~mL}$ Erlenmeyer flasks containing $45 \mathrm{~mL}$ of the former medium and incubated at $30^{\circ} \mathrm{C}$ for $8 \mathrm{~h}$, 
Table 1. Coded levels and real values (in parentheses) for the first factorial design (17 trials) and glucosyltransferase activity $\left(\mathrm{UmL}^{-1}\right)$.

\begin{tabular}{|c|c|c|c|c|}
\hline \multirow[t]{2}{*}{ Assay } & \multicolumn{3}{|c|}{ Variable $\left(\mathrm{g} \mathrm{L}^{-1}\right)$} & \multirow{2}{*}{$\begin{array}{l}\text { Enzyme } \\
\text { activity } \\
\left(\mathrm{UmL}^{-1}\right)\end{array}$} \\
\hline & SCM & CSL & YEP & \\
\hline 1 & $-1(70.24)$ & $-1(42.14)$ & $-1(7.23)$ & 3.50 \\
\hline 2 & $+1(129.76)$ & $-1(42.14)$ & $-1(7.23)$ & 4.46 \\
\hline 3 & $-1(70.24)$ & $+1(77.86)$ & $-1(7.23)$ & 3.67 \\
\hline 4 & $+1(129.76)$ & $+1(77.86)$ & $-1(7.23)$ & 5.28 \\
\hline 5 & $-1(70.24)$ & $-1(42.14)$ & $+1(16.77)$ & 3.49 \\
\hline 6 & $+1(129.76)$ & $-1(42.14)$ & $+1(16.77)$ & 5.32 \\
\hline 7 & $-1(70.24)$ & $+1(77.86)$ & $+1(16.77)$ & 3.78 \\
\hline 8 & $+1(129.76)$ & $+1(77.86)$ & $+1(16.77)$ & 0.53 \\
\hline 9 & $-1.68(50)$ & $0(60)$ & $0(12)$ & 3.27 \\
\hline 10 & $+1.68(150)$ & $0(60)$ & $0(12)$ & 1.43 \\
\hline 11 & $0(100)$ & $-1.68(30)$ & $0(12)$ & 4.92 \\
\hline 12 & $0(100)$ & $+1.68(90)$ & $0(12)$ & 3.19 \\
\hline 13 & $0(100)$ & $0(60)$ & $-1.68(4)$ & 5.73 \\
\hline 14 & $0(100)$ & $0(60)$ & $+1.68(20)$ & 5.73 \\
\hline 15 & $0(100)$ & $0(60)$ & $0(12)$ & 4.97 \\
\hline 16 & $0(100)$ & $0(60)$ & $0(12)$ & 5.10 \\
\hline 17 & $0(100)$ & $0(60)$ & $0(12)$ & 5.40 \\
\hline
\end{tabular}

Table 2. Coded levels and real values (in parentheses) for the second factorial design (17 trials) and glucosyltransferase activity $\left(\mathrm{U} \mathrm{mL}^{-1}\right)$.

\begin{tabular}{|c|c|c|c|c|}
\hline \multirow[t]{2}{*}{ Assay } & \multicolumn{3}{|c|}{ Variable $\left(\mathrm{g} \mathrm{L}^{-1}\right)$} & \multirow{2}{*}{$\begin{array}{l}\text { Enzyme } \\
\text { activity } \\
\left(\mathrm{UmL}^{-1}\right)\end{array}$} \\
\hline & SCM & CSL & YEP & \\
\hline 1 & $-1(97.74)$ & $-1(72.14)$ & $-1(2.02)$ & 2.94 \\
\hline 2 & +1 (32.26) & $-1(72.14)$ & $-1(2.02)$ & 5.25 \\
\hline 3 & $-1(97.74)$ & $+1(107.86)$ & $-1(2.02)$ & 2.94 \\
\hline 4 & $+1(32.26)$ & $+1(107.86)$ & $-1(2.02)$ & 3.31 \\
\hline 5 & $-1(97.74)$ & $-1(72.14)$ & $+1(7.98)$ & 3.38 \\
\hline 6 & $+1(32.26)$ & $-1(72.14)$ & +1(7.98) & 6.37 \\
\hline 7 & $-1(97.74)$ & $+1(107.86)$ & $+1(7.98)$ & 4.21 \\
\hline 8 & $+1(32.26)$ & $+1(107.86)$ & $+1(7.98)$ & 4.45 \\
\hline 9 & $-1.68(10)$ & $0(90)$ & $0(5)$ & 2.64 \\
\hline 10 & $+1.68(120)$ & $0(90)$ & $0(5)$ & 4.89 \\
\hline 11 & $0(65)$ & $-1.68(60)$ & $0(5)$ & 4.71 \\
\hline 12 & $0(65)$ & $+1.68(120)$ & $0(5)$ & 3.90 \\
\hline 13 & $0(65)$ & $0(90)$ & $-1.68(0)$ & 4.93 \\
\hline 14 & $0(65)$ & $0(90)$ & $+1.68(10)$ & 4.19 \\
\hline 15 & $0(65)$ & $0(90)$ & $0(5)$ & 4.33 \\
\hline 16 & $0(65)$ & $0(90)$ & $0(5)$ & 4.21 \\
\hline
\end{tabular}

Table 3. Coded levels and real values (in parentheses) for the third factorial design (17 trials) and glucosyltransferase activity $\left(\mathrm{U} \mathrm{ml}^{-1}\right)$.

\begin{tabular}{|c|c|c|c|c|}
\hline \multirow[t]{2}{*}{ Assay } & \multicolumn{3}{|c|}{ Variable $\left(\mathrm{g} \mathrm{L}^{-1}\right)$} & \multirow{2}{*}{$\begin{array}{l}\text { Enzyme } \\
\text { activity } \\
\left(\mathrm{UmL}^{-1}\right)\end{array}$} \\
\hline & SCM & CSL & YEP & \\
\hline 1 & $-1(70.24)$ & $-1(36.19)$ & $-1(4.43)$ & 4.26 \\
\hline 2 & $+1(129.76)$ & $-1(36.19)$ & $-1(4.43)$ & 5.42 \\
\hline 3 & $-1(70.24)$ & $+1(83.81)$ & $-1(4.43)$ & 4.12 \\
\hline 4 & $+1(129.76)$ & $+1(83.81)$ & $-1(4.43)$ & 5.35 \\
\hline 5 & $-1(70.24)$ & $-1(36.19)$ & $+1(11.57)$ & 4.52 \\
\hline 6 & $+1(129.76)$ & $-1(36.19)$ & $+1(11.57)$ & 5.89 \\
\hline 7 & $-1(70.24)$ & $+1(83.81)$ & $+1(11.57)$ & 5.63 \\
\hline 8 & $+1(129.76)$ & $+1(83.81)$ & $+1(11.57)$ & 7.20 \\
\hline 9 & $-1.68(50)$ & $0(60)$ & $0(8)$ & 4.85 \\
\hline 10 & $+1.68(150)$ & $0(60)$ & $0(8)$ & 6.42 \\
\hline 11 & $0(100)$ & $-1.68(20)$ & $0(8)$ & 5.77 \\
\hline 12 & $0(100) 0$ & $+1.68(1000)$ & $0(8)$ & 6.27 \\
\hline 13 & $0(100)$ & $0(60)$ & $-1.68(2)$ & 6.53 \\
\hline 14 & $0(100)$ & $0(60)$ & $+1.68(14)$ & 6.04 \\
\hline 15 & $0(100)$ & $0(60)$ & $0(8)$ & 6.30 \\
\hline 16 & $0(100)$ & $0(60)$ & $0(8)$ & 6.69 \\
\hline 17 & $0(100)$ & $0(60)$ & $0(8)$ & 6.95 \\
\hline
\end{tabular}

shaken at $200 \mathrm{rpm}$. The culture broth was centrifuged at 10,070 $\mathrm{xg}$ for $15 \mathrm{~min}$ at $5^{\circ} \mathrm{C}$, and the precipitated cell mass was used for the determination of glucosyltransferase activity. For the extraction of intracellular enzyme, the cell mass was washed twice with distilled water and then suspended in $50 \mathrm{~mL}$ citratephosphate buffer $0.05 \mathrm{M}, \mathrm{pH}$ 6.0. The cell suspension was cooled to $5^{\circ} \mathrm{C}$ and disrupted by ultrasonic vibration Labline Ultra-Tip (Labline Instruments, Inc., Illinois, USA). After cell wall disruption, the samples were centrifuged at $12,300 \mathrm{x} g$ for $15 \mathrm{~min}$ at $5^{\circ} \mathrm{C}$. The enzyme activity of the supernatant was determined.

\section{Glucosyltransferase activity}

The glucosyltransferase activity was performed by the increase of the reducing power from a solution containing sucrose, described by Park (11) with modifications. A mixture of $450 \mu \mathrm{L}$ of a $4.0 \%(\mathrm{w} / \mathrm{v})$ sucrose solution in $0.05 \mathrm{M}$ citratephosphate buffer, $\mathrm{pH} 6.0$ and $50 \mu \mathrm{L}$ of enzyme solution was incubated for $20 \mathrm{~min}$. at $35^{\circ} \mathrm{C}$. Reducing sugars were measured by the Somogyi method (15) using glucose as standard. One activity unit (U) of glucosyltransferase is defined as the amount of enzyme that liberates one mmol of reducing sugars (isomaltulose) minute $\mathrm{e}^{-1} \mathrm{~mL}^{-1}$ of the enzyme from sucrose under standard assay conditions. 


\section{RESULTS AND DISCUSSIONS}

\section{First Experimental Design}

The experimental conditions and the results for glucosyltransferase activity to the first $2^{3}$-FCCD are shown in Table 1. The effect estimates for the first $2^{3}$-FCCD for each variable, sugar cane molasses (SCM), corn steep liquor (CSL) and yeast extract Prodex Lac SD ${ }^{\circledR}$ (YEP) were determinated and reported in Table 4. An estimation of a main effect is obtained by evaluating in the difference in process performance caused by a change from the low $(-1)$ to the high $(+1)$ level of the corresponding factor. In this case, the process performance was measured by the glucosyltransferase activity response. In addition, both the $\mathrm{t}$-test and $\mathrm{p}$-value statistical parameters were used to confirm the significance of factors studied. The t-value that measure how large the coefficient is in relation to its standard error was obtained by dividing each coefficient by its standard error. The p-value is the chance of getting a larger $\mathrm{t}$-value (in absolute value) by chance by itself. A small p-value suggested that the coefficient was a large signal in comparison to the noise
1. The independent and the dependent variables were fitted to the second-order model equation. They were examined in terms of the goodness of fit. Furthermore, the analysis of variance (ANOVA) was used to evaluate the adequacy of the fitted model. The R-square (correlation coefficient) value provides a measure of how much of the variability in the observed response values could be explained by the experimental factors and their interactions. A good model explains most of the variations in the response. The closer the R-square value is to 1.0, the stronger the model and the better are the response predictions. On the basis of the ANOVA, as shown in Table 5, a second order model (Equation 3) was estabilished, describing the enzyme activity as a function of SCM, CSL and YEP concentrations. The pure error was very low, indicating a good reproducibility of the experimental data. Based on the $\mathrm{F}$ test, the model is predictive, since its calculated $\mathrm{F}$ value is higher than the critical $\mathrm{F}$ value and the regression coefficient is close to unity. The coded model was used to generate response surfaces and contour curves (Figs. 2 and 3) for the analysis of the variable effects on glucosyltransferase activity:

Table 4. Main effects and interactions analysis for glucosyltransferase activity from the first and second factorial design.

\begin{tabular}{|c|c|c|c|c|c|c|c|c|c|}
\hline \multicolumn{5}{|c|}{ First factorial design } & \multicolumn{5}{|c|}{ Second factorial design } \\
\hline Factor & Effect & Std. Err. & $\mathrm{t}$-value & p-value & Factor & Effect & Std. Err. & $\mathrm{t}$-value & p-value \\
\hline (1)SCM(L) & -0.29 & 0.12 & -2.39 & 0.1390 & (1)SCM (L) & 1.418 & 0.045 & 31.195 & $0.0204^{*}$ \\
\hline $\mathrm{SCM}(\mathrm{Q})$ & -2.09 & 0.13 & -15.80 & $0.0040^{*}$ & $\operatorname{SCM}(\mathrm{Q})$ & -0.409 & 0.055 & -7.395 & 0.0856 \\
\hline (2)CSL (L) & -0.94 & 0.12 & -7.84 & $0.0159^{*}$ & (2)CSL(L) & -0.647 & 0.045 & -14.223 & $0.0447^{*}$ \\
\hline $\operatorname{CSL}(\mathrm{Q})$ & -0.88 & 0.13 & -6.66 & $0.0218^{*}$ & CSL $(Q)$ & -0.024 & 0.055 & -0.437 & 0.7379 \\
\hline (3)YEP(L) & -0.56 & 0.12 & -4.65 & $0.0432^{*}$ & (3) YEP(L) & 0.401 & 0.045 & 8.817 & 0.0719 \\
\hline $\mathrm{YEP}(\mathrm{Q})$ & 0.31 & 0.13 & 2.31 & 0.1466 & $\mathrm{YEP}(\mathrm{Q})$ & 0.160 & 0.055 & 2.894 & 0.2118 \\
\hline (1) $\mathrm{x}(2)$ & -1.11 & 0.16 & -7.06 & $0.0195^{*}$ & (1) $\mathrm{x}(2)$ & -1.172 & 0.059 & -19.743 & $0.0322^{*}$ \\
\hline (1) $\times(3)$ & -1.00 & 0.16 & -6.37 & $0.0238^{*}$ & (1) $\mathrm{x}(3)$ & 0.141 & 0.059 & 2.374 & 0.2538 \\
\hline (2) $x(3)$ & -1.37 & 0.16 & -8.77 & $0.0128^{*}$ & (2) $\mathrm{x}(3)$ & 0.209 & 0.059 & 3.523 & 0.1761 \\
\hline
\end{tabular}

$(\mathrm{L})$ : linear factor; $(\mathrm{Q})$ : quadratic factor; *Significant factors $(\mathrm{p} \leq 05)$.

because it was too large to have arisen by chance by itself. In this case, $\mathrm{p} \leq 0.05$ suggested significance at the 0.05 level. This also corresponded to a $95 \%$ of confidence level for test of the hypothesis that the effects (or coefficients) in this situation were equal to zero. Small p-values were associated with larger t-value seeing that they imply that the effects (or coefficients) were too much greater than its standard error. It can be seen that all variables and the interactions between the three factors concerning the glucosyltransferase activity were statistically significant.

The variable SCM (Q) showed the highest effect in glucosyltransferase activity. An increase in SCM concentration resulted in a negative influence. A fitting model was accomplished for the first experimental design as shown in Table
Table 5. ANOVA for the first factorial design.

\begin{tabular}{lcccc}
\hline $\begin{array}{c}\text { Source } \\
\text { of variation }\end{array}$ & $\begin{array}{c}\text { Sum of } \\
\text { square }\end{array}$ & $\begin{array}{c}\text { Degrees } \\
\text { of freedom }\end{array}$ & Mean square & $\begin{array}{c}\text { F-ratio } \\
\text { (model } \\
\text { significance) }\end{array}$ \\
\hline Regression & 29.78 & 6 & 4.96 & $9.78^{\mathrm{a}}$ \\
Residual & 5.07 & 10 & 0.51 & \\
Lack of fit & 4.98 & 8 & 0.62 & $12.40^{\mathrm{b}}$ \\
Pure error & 0.10 & 2 & 0.05 & \\
Total & 34.85 & 16 & & \\
\hline
\end{tabular}

Correlation coefficient: $\mathrm{R}^{2}=0.80 ; \mathrm{F}_{0.95,6,10}=3.22 ; \mathrm{F}_{0.95,8,2}=19.37$; ${ }^{\text {F- }}$-ratio (regression/residual); ${ }^{\text {F}}$-ratio (lack of fit/pure error). 


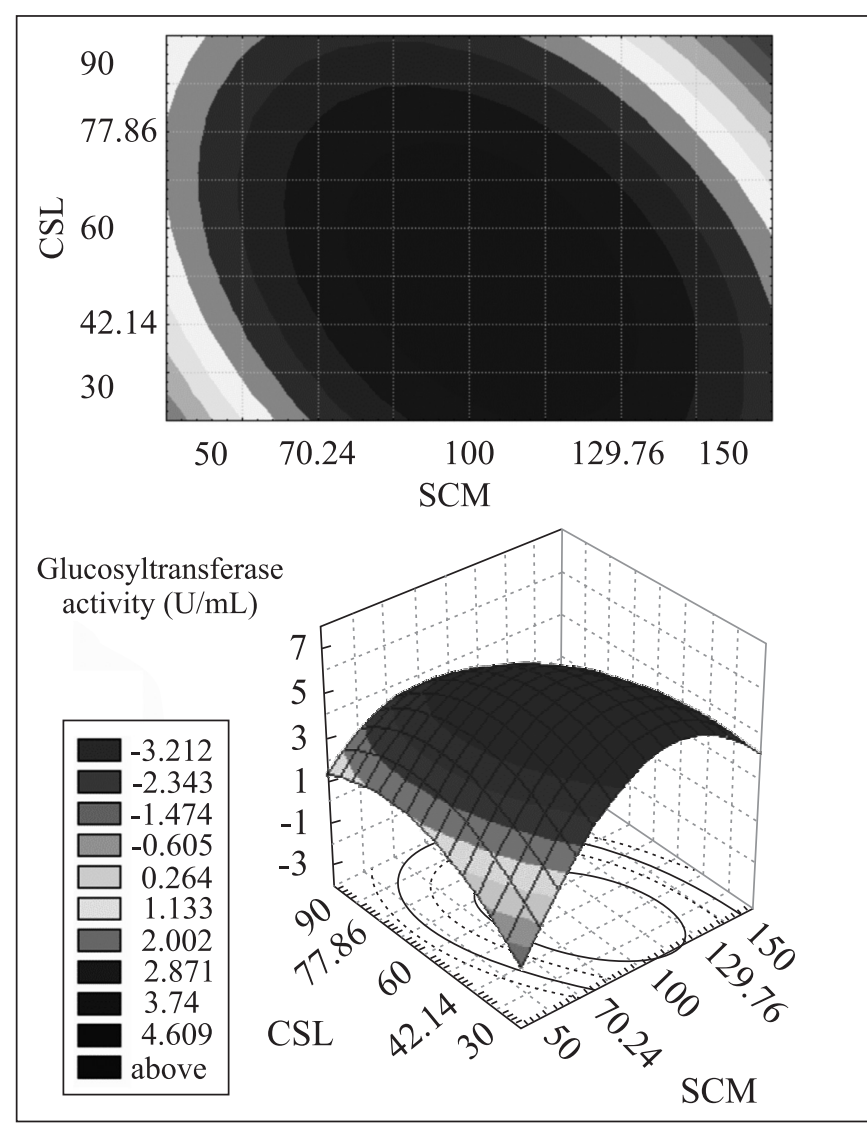

Figure 2. Contour curve and response surface for the glucosyltransferase activity as a function of CSL and SCM concentrations, according to the first experimental design.

$$
\begin{aligned}
& y=5.17-1.04 x_{1}^{2}-0.47 x_{2}-0.44 x_{2}^{2}-0.28 x_{3} \\
& -0.55 x_{1} \cdot x_{2}-0.50 x_{1} \cdot x_{3}-0.68 x_{2} \cdot x_{3}
\end{aligned}
$$

where $y$ is the predicted response and $x_{1}, x_{2}$ and $x_{3}$ are the coded values of sugar cane molasses, corn steep liquor and yeast extract Prodex Lac SD ${ }^{\circledR}$, respectively. As can be seen in Figs. 2 and 3, the best SCM concentration is between 70 and $130 \mathrm{~g} \mathrm{~L}^{-1}$. Not only an increase in CSL but also a decrease in YEP concentrations led to an increase in glucosyltransferase activity. In a subsequent experimental design, higher concentrations of CSL and lower concentrations of SCM and YEP were chosen to produce maximum enzyme activity.

\section{Second Experimental Design}

The assays and the results for the second $2^{3}$-FCCD are shown in Table 2. The effect estimates were determined being reported in Table 3. The analysis of the effects shows that the SCM (L) is the most important variable, since an increase in the concentration of this variable from 10 to $120 \mathrm{~g} \mathrm{~L}^{-1}$ led to an

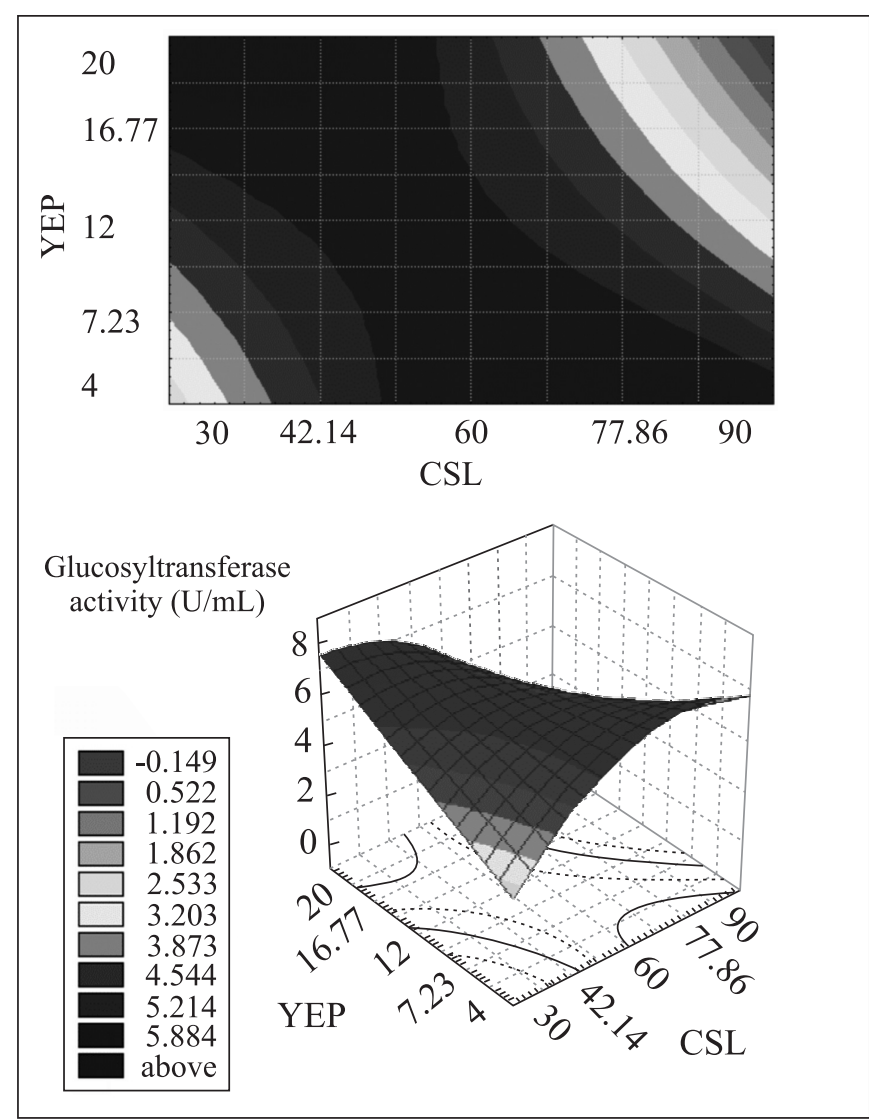

Figure 3. Contour curve and response surface for the glucosyltransferase activity as a function of YEP and CSL concentrations, according to the first experimental design.

increase in glucosyltransferase activity. However, the variable CSL had a negative influence in the enzyme activity. In other words, the increase of this variable from 60 to $120 \mathrm{~g} \mathrm{~L}^{-1}$ led to a decreased in the enzyme activity. The increase in YEP concentration from 0 to $10 \mathrm{~g} \mathrm{~L}^{-1}$ did not show significant influence in glucosyltransferase activity $(\mathrm{p} \leq 0.05)$, while its interaction with CSL was statistically significant for the enzyme activity. In the third experimental design, the SCM and YEP concentration ranges were increased and, in the case of CSL, it decreased. On the basis of the ANOVA, shown in Table 6, a second order coded model (Equation 4) was established, describing the glucosyltransferase activity as a function of SCM, CSL and YEP concentrations:

$$
y=4.28-0.71 x_{1}-0.32 x_{2}-0.59 x_{1} \cdot x_{2}
$$

where $y$ is the predicted response and $x_{1}, x_{2}$ and $x_{3}$ are the coded values of sugar cane molasses, corn steep liquor and yeast extract Prodex Lac $\mathrm{SD}^{\circledR}$, respectively. Based on the $\mathrm{F}$ 
Table 6. ANOVA for the second factorial design.

\begin{tabular}{lcccc}
\hline $\begin{array}{c}\text { Source } \\
\text { of variation }\end{array}$ & $\begin{array}{c}\text { Sum of } \\
\text { square }\end{array}$ & $\begin{array}{c}\text { Degrees } \\
\text { of freedom }\end{array}$ & Mean square & $\begin{array}{c}\text { F-ratio } \\
\text { (model } \\
\text { significance) }\end{array}$ \\
\hline Regression & 11.04 & 2 & 5.52 & $21.89^{\mathrm{a}}$ \\
Residual & 3.28 & 13 & 0.25 & \\
Lack of fit & 3.28 & 12 & 0.27 & $27.00^{\mathrm{b}}$ \\
Pure error & 0.00 & 1 & 0.01 & \\
Total & 14.31 & 15 & & \\
\hline
\end{tabular}

Correlation coefficient: $\mathrm{R}^{2}=0.77 ; \mathrm{F}_{0.95,2,13}=3.81 ; \mathrm{F}_{0.95,11,1}=242.98$; ${ }^{\mathrm{a}} \mathrm{F}-$ ratio (regression/residual); ${ }^{\mathrm{b}} \mathrm{F}$-ratio (lack of fit/pure error).

test, the model is predictive, since the $\mathrm{F}$ value calculated is 5.75 times higher than the critical F value. After the ANOVA, the response surfaces and contour curves (Figs. 4 and 5) were obtained using Equation 4. It can be seen that an increase in SCM and a decrease in CSL concentrations led to an increase

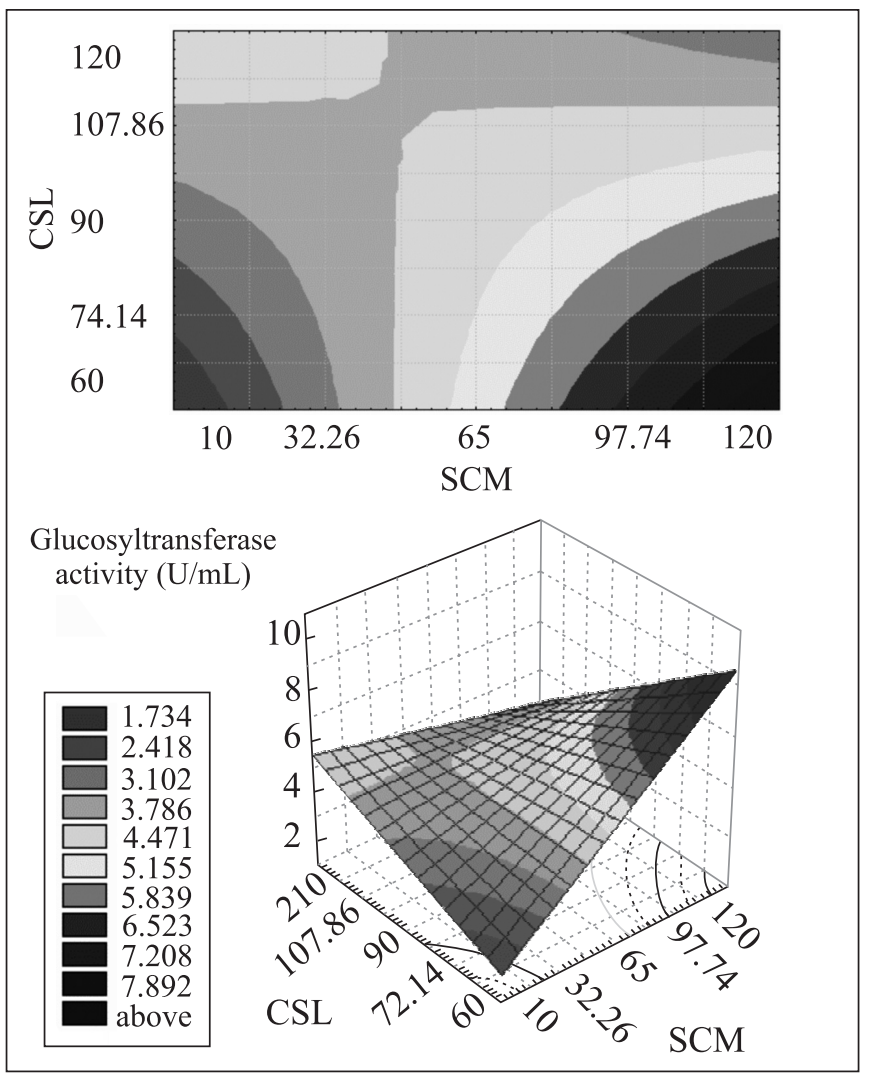

Figure 4. Contour curve and response surface for the glucosyltransferase activity as a function of CSL and SCM concentrations, according to the second experimental design. in enzyme activity. The increase or increase in YEP concentrations did not show significant influence on glucosyltransferase activity. Based on these results, in a subsequent experimental design, higher concentrations of SCM and YEP and lower concentration of CSL were chosen to obtain maximum enzyme activity.

\section{Third Experimental Design}

The experimental conditions and the results are shown in Table 3 and Figs. 6 and 7. Table 3 presents the $2^{3}$-FCCD used to evaluate the effect of the independent variables sugar cane molasses (SCM), corn steep liquor (CSL) and yeast extract Prodex Lac SD ${ }^{\circledR}$ (YEP) and the dependent variable in glucosyltransferase activity. Table 7 presents the ANOVA, demonstrating that the model was significant in a confidence level of $85 \%$ which is evident in the F-test $\left(\mathrm{F}_{\text {model }}\right.$ exceeds 5.64 times the tabulated value of F). All the components of the culture medium were the most important effects in the glucosyltransferase production. After the ANOVA analysis and from the validation of the studied parameters, the

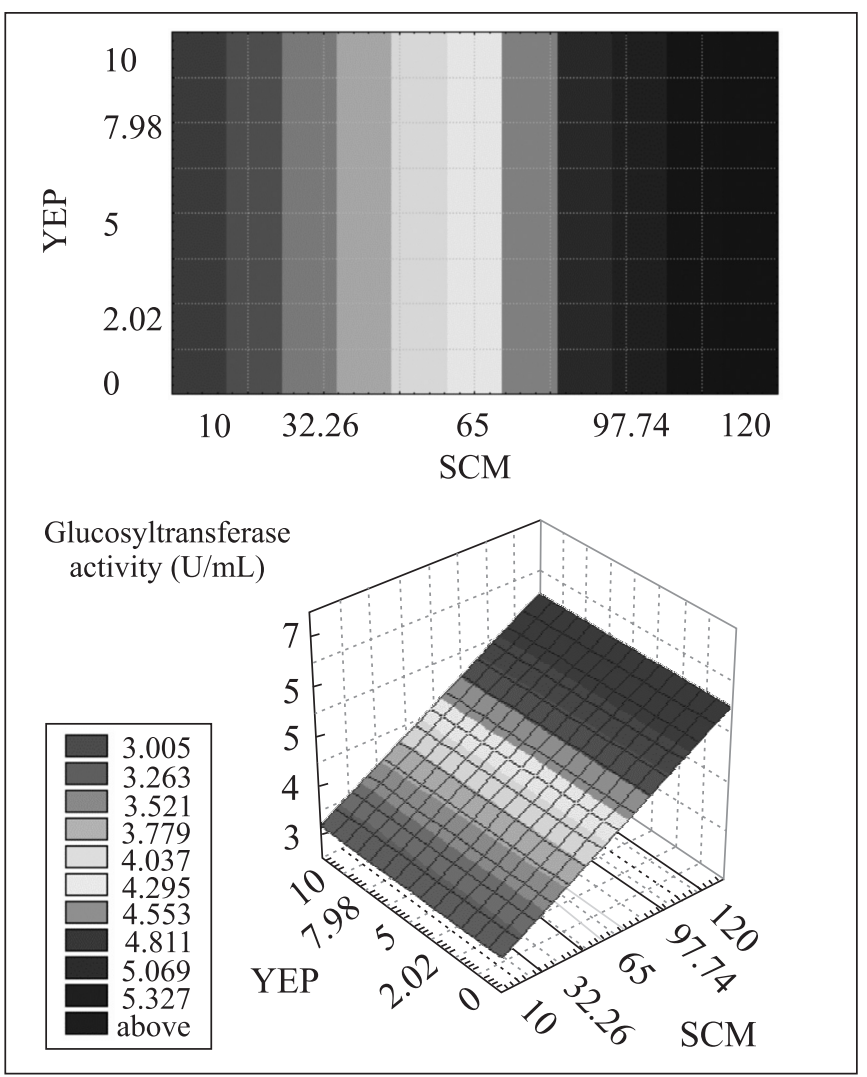

Figure 5. Contour curve and response surface for the glucosyltransferase activity as a function of YEP and SCM concentrations, according to the second experimental design. 


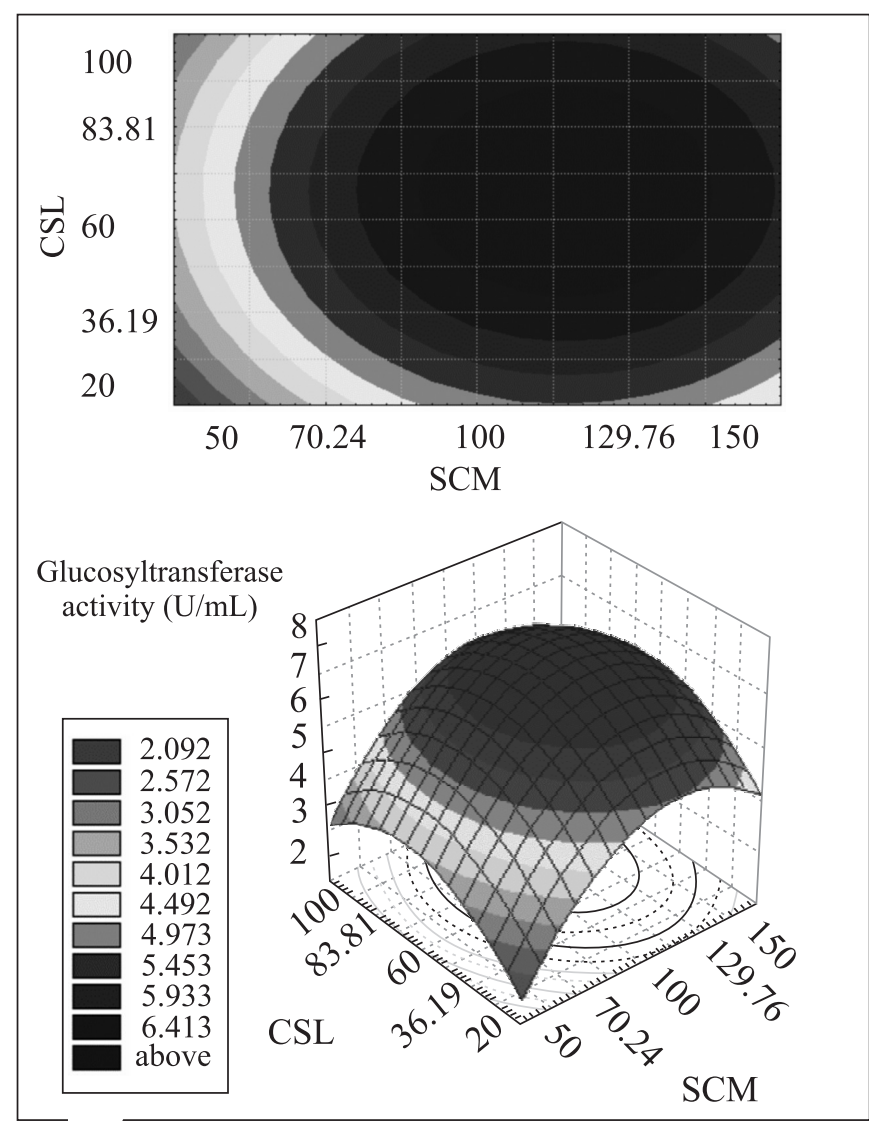

Figure 6. Contour curve and response surface for the glucosyltransferase activity as a function of CSL and SCM concentrations, according to the third experimental design.

glucosyltransferase activity model (equation 5) was used to obtain the response surfaces and contour curves:

$y=5.65-0.47 x_{1}-1.38 x_{1}{ }^{2}-0.73 x_{2}-0.77 x_{2}^{2}-0.58 x_{3}^{2}$

Table 7. ANOVA for the third factorial design.

\begin{tabular}{lcccc}
\hline $\begin{array}{c}\text { Source } \\
\text { of variation }\end{array}$ & $\begin{array}{c}\text { Sum of } \\
\text { square }\end{array}$ & $\begin{array}{c}\text { Degrees } \\
\text { of freedom }\end{array}$ & Mean square & $\begin{array}{c}\text { F-ratio } \\
\text { (model } \\
\text { significance) }\end{array}$ \\
\hline Regression & 11.45 & 5 & 2.29 & $11.50^{\mathrm{a}}$ \\
Residual & 2.19 & 11 & 0.20 & \\
Lack of fit & 1.97 & 9 & 0.21 & $1.91^{\mathrm{b}}$ \\
Pure error & 0.22 & 2 & 0.11 & \\
Total & 13.65 & 16 & & \\
\hline
\end{tabular}

Correlation coefficient: $\mathrm{R}^{2}=0.72 ; \mathrm{F}_{0.85,5,11}=2.04 ; \mathrm{F}_{0.85,9,2}=6.04 ;{ }^{\mathrm{a}} \mathrm{F}$-ratio (regression/residual); ${ }^{\mathrm{b}} \mathrm{F}$-ratio (lack of fit/pure error).

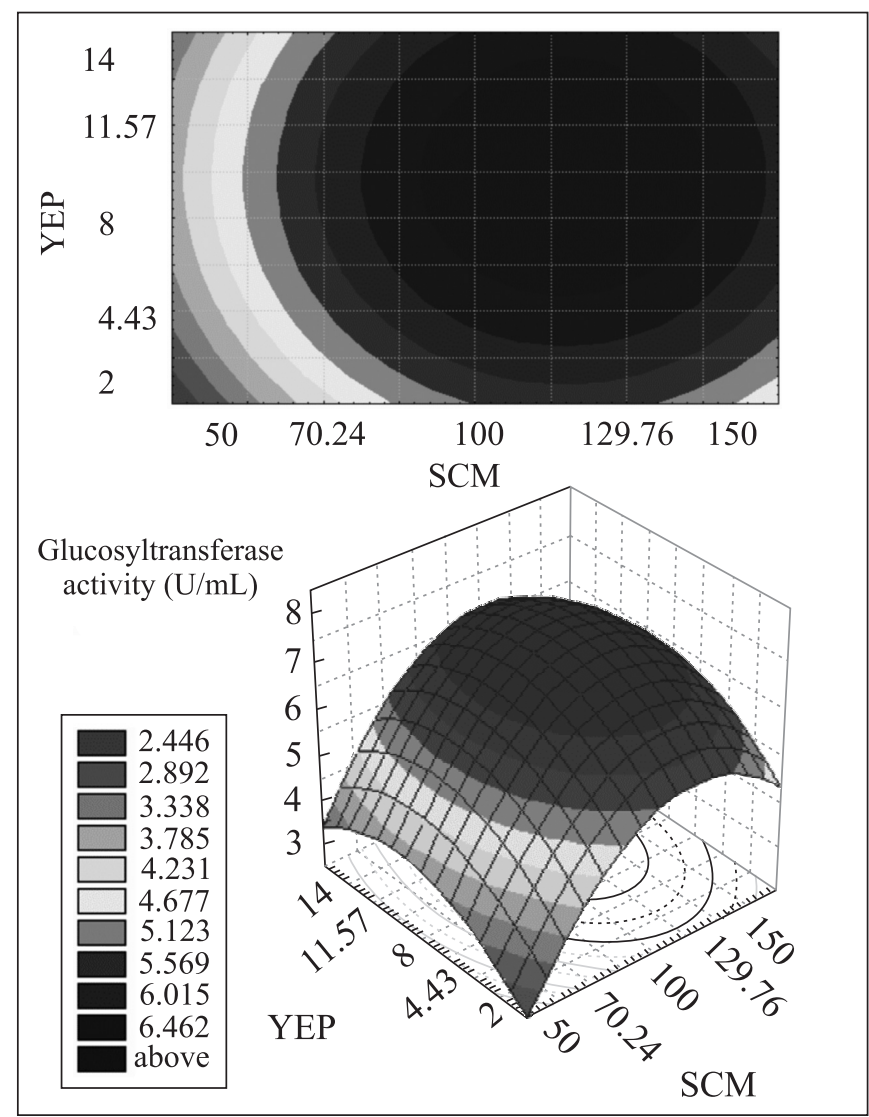

Figure 7. Contour curve and response surface for the glucosyltransferase activity as a function of YED and SCM concentrations, according to the third experimental design.

where $y$ is the predicted response and $x_{1}, x_{2}$ and $x_{3}$ are the coded values of sugar cane molasses, corn steep liquor and yeast extract Prodex Lac SD ${ }^{\circledR}$, respectively. The contour curves and response surfaces showing the effect of SCM, CSL, and YEP are shown in Figs. 6 and 7. The statistical optimal values of variables are obtained when moving along the major and the minor axis of the contour. The response at the central point yields to a maximum glucosyltransferase production. In the study of the culture medium optimization by Erwinia sp. D12 for the production of glucosyltransferase using RSM, the optimal value for concentrations of $x_{1}, x_{2}$ and $x_{3}$ (sugar cane molasses, corn steep liquor and yeast extract Prodex Lac SD ${ }^{\circledR}$ ) were found to be $100 \mathrm{gL}^{-1}, 60 \mathrm{gL}^{-1}$ and $8 \mathrm{gL}^{-1}$, respectively. It was obtained $6.65 \mathrm{U} \mathrm{mL}^{-1}$ (mean of the central points) after $8 \mathrm{~h}$ fermentation at $30^{\circ} \mathrm{C}$. This value is approximately 9.5 times higher than the one produced by Park et al. (11) using strain Klebsiella sp. in a culture medium composed by beef extract and sucrose. Moraes et al. (8) obtained $12.8 \mathrm{U} \mathrm{mL}^{-1}$ of glucosyltranferase activity from Erwinia sp. cells. In this case, the culture medium 
was composed by sugar cane molasses, bacteriological peptone and beef extract. The glucosyltransferase purified from Pseudomonas mesoacidophila MX-45, isolated by Nagai et al. (9), presented $13.89 \mathrm{U}$ mg protein ${ }^{-1}$. These authors used a synthetic media composed by beef extract, peptone, $\mathrm{NaCl}$ and $\mathrm{Na}_{2} \mathrm{HPO}_{4}$. Using Klebsiella planticola CCRC 19112, Huang et al. (4) obtained a maximum glucosyltransferase activity of 5.2 U $\mathrm{mL}^{-1}$ using a culture medium composed by sucrose, tryptic soy brith and frutose. Overall, in this work, corn steep liquor (agroindustrial residue) and commercial yeast extract were used with the purpose of resulting in a low cost culture media. The results were satisfatory and the components sugar cane molasses and corn steep liquor are very useful carbon and nitrogen soucers, respectively to enzyme production.

\section{ACKNOWLEDGMENTS}

The financial support from the Coordenação de Aperfeiçoamento de Pessoal de Nível Superior (CAPES), Financiadora de Estudos e Projetos em Pesquisa (FINEP) and GETEC Guanabara Química Industrial S.A. We thank the Prodesa Produtos Especiais para Alimentos S/A for the supply of the yeast extract Prodex Lac SD ${ }^{\circledR}$ and the Corn Products Brasil for the corn steep liquor supply.

\section{RESUMO \\ Produção de glicosiltransferase por Erwinia sp. utilizando planejamento experimental e metodologia de superfície de resposta}

A glicosiltransferase obtida pela linhagem Erwinia sp. é uma enzima intracelular que catalisa a conversão de sacarose em isomaltulose. A isomaltulose é um dissacarídeo redutor, não cariogênico e comercialmente utilizado em alimentos como substituto da sacarose. A metodologia de superfície de resposta e planejamento fatorial composto central- $2^{3}$ foram utilizados para otimizar o meio de cultivo para a produção de glicosiltransferase de Erwinia sp. em frascos sob agitação a $200 \mathrm{rpm}$ e $30^{\circ} \mathrm{C}$. As três variáveis independentes envolvidas no estudo foram o melaço de cana de açúcar, a água de maceração de milho e o extrato de levedura Prodex Lac SD. As análises estatísticas dos resultados mostraram que, dentro da faixa estudada das concentrações dos componentes de meio de cultivo, todas as variáveis apresentaram efeito significativo na produção de glicosiltransferase. $\mathrm{O}$ meio de cultivo otimizado foi composto de $100 \mathrm{gL}^{-1}$ de melaço de cana de açúcar, $60 \mathrm{gL}^{-1}$ de água de maceração de milho e $8 \mathrm{gL}^{-1} \mathrm{de}$ extrato de levedura Prodex Lac SD, apresentando atividade de glicosiltransferase de $6.65 \mathrm{U} \mathrm{mL}^{-1}$.

Palavras-chaves: glicosiltransferase, isomaltulose, otimização, superfície de resposta

\section{REFERENCES}

1. Cheethan, P.S.J.; Imber, C.E.; Isherwood, J. The formation of isomaltulose by immobilized Erwinia rhapontici. Nature., 299, 628$631,1982$.

2. Hamada, S. Role of sweeteners in the etiology and prevention of dental caries. Pure Appl. Chem., 74(7), 2002.

3. Hashimoto, H.; Yamada, K.; Yoshimura, J. Glucosylation of methyl $\beta$-D-arabinofuranoside with 6'-chloro-6'-deoxysucrose and immobilized Protaminobacter rubrum. Biotechnol. Lett., 9(12), 849-854, 1987.

4. Huang, J.H.; Hsu, L.H.; Su Y.C. Conversion of sucrose to isomaltulose by Klebsiella planticola CCRC 19112. J. Ind. Microbiol. Biotechnol., 21, 22-27, 1998.

5. Kawai, K.; Okuda, Y.; Yamashita, K. Changes in blood glucose and insulin after an oral palatinose administration in normal subjects. Endocrinol. Japon., 32(6), 933-936, 1985.

6. Kawai, K.; Yoshikawa, H.; Murayama, Y.; Okuda, Y.; Yamashita K. Usefulness of palatinose as a caloric sweetener for diabetic patients. Horm. Metabol. Res., 21, 338-340, 1989

7. Lina, B.A.R.; Smits-Van Prooije, A.E.; Waalkens-Berendsen, D.H. Embryotoxicity/teratogenicity study with isomaltulose (palatinose) in rats. Food Chem. Toxicol., 35, 309-314, 1997

8. Moraes, A.L.L.; Steckelberg, C.; Sato, H.H.; Pinheiro, A. Produção de isomaltulose a partir da transformação enzimática da sacarose utilizando-se Erwinia sp D12 imobilizada com alginato de cálcio. Ciênc. Tecnol. Aliment., 25(1), 95-102, 2005.

9. Nagai, Y.; Sugitani, T.; Tsuyuki, K. Characterization of $\alpha$ glucosyltransferase from Pseudomonas mesoacidophila MX-45. Biosci., Biotechnol., Biochem., 58(10), 1789-1793, 1994.

10. Ooshima, T.; Izumitani, A.; Sobue, S.; Okahashi, N.; Hamada S. Noncariogenicity of the disaccharide palatinose in experimental dental caries of rats. Infect. Immun., 39(1), 43-49, 1983.

11. Park, Y.K.; Uekane, R.T.; Pupin, A.M. Conversion of sucrose to isomaltulose by microbial glucosyltransferase. Biotechnol. Lett., 14(9), 37, 547-551, 1992.

12. Rao, J.R.; Kim, C.H.; Rhee, S.K. Statistical optimization of medium for the production of recombinant hirudin from Saccharomyces cerevisae using response surface methodology. Process Biochem., 35(7), 639-647, 2000

13. Sasaki, N.; Topitsoglou, V.; Takazoe, I.; Frostell, G. Cariogenicity of isomaltulose (palatinose), sucrose and mixture of these sugars in rats infected with Streptococcus mutans E- 49. Swed. Dent. J., 9, 149$155,1985$.

14. Shimizu, J.; Suzuki, K.; Nakajima, Y. Method of producing an immobilized $\alpha$-glicosiltransferase useful in the production of palatinose from sucrose. U.K. Pat. 2,082,591., Aug. 13, 1982.

15. Somogyi, M. A new reagent for the determination of sugars. J. Biol. Chem., 160, 61-68, 1945.

16. Takazoe, I. New trends on sweeteners in Japan. Int. Dent. J. 35, 58$65,1985$.

17. Takazoe, I.; Otha, K.; Shimizu, J.; Suzuki, K.; Iwakura, T.; Nakajina, Y. Low-cariogenic sweeteners. U.S. Pat. 4,556,429., Dec. 3, 1985.

18. Topitsoglou, V.; Sasaki, N.; Frostell, G. Effect of frequent rinses with isomaltulose (palatinose) solution on acid production in human dental plaque. Caries Res., 18, 47-51, 1984. 